\title{
Pre-service Social Studies Teachers' Viewpoints about Atatürk as Founding and Transformational Leader
}

\author{
Cengiz Dönmez ${ }^{1}$, Salih Uslu ${ }^{2, *}$, Ercenk Hamarat ${ }^{1}$ \\ ${ }^{1}$ Faculty of Gazi Education, Gazi University, Ankara \\ ${ }^{2}$ Faculty of Education, Nigde Omer Halisdemir University, Turkey
}

Copyright $\mathrm{O} 2017$ by authors, all rights reserved. Authors agree that this article remains permanently open access under the terms of the Creative Commons Attribution License 4.0 International License

\begin{abstract}
The aim of the current study is to identify the opinions of pre-service social studies teachers about Atatürk as a founding and transformational leader. The sample of the study comprises 180 pre-service teachers in the social studies teaching department of an education faculty in a public university. The data have been collected through an open-ended questionnaire prepared by the researchers. Content analysis has been used for the data analysis; the findings have been presented in tables through the frequency technique which is used for quantifying qualitative data, and percentage distributions have been given. Moreover, direct quotations from the opinions of the participants have been included so that quantitative data could be interpreted in a more meaningful way. The findings of the study show that the viewpoints of the pre-service teachers about Atatürk as a founding and transformational leader mostly gather around Atatürk as the founder of Turkish Republic, a foresighted leader and a transformational leader.
\end{abstract}

Keywords Ataturk, Founding Leader, Transformational Leader, Social Studies, Pre-service Teachers

\section{Introduction}

Mustafa Kemal Atatürk, who has the characteristics of both a founding and a transformational leader, is one of the most important leaders in the history. This is because he both founded Turkish Republic and transformed this state in accordance with the necessities of the time. Thus, Atatürk is a great soldier and statesman who has affected the first half of the twentieth century with his outstanding leadership. There are two crucial points that separate him from the other leaders of his age. These are his domestic and foreign policies. While his domestic policy is based on the idea of founding a political system that can survive after his death, his foreign policy is narrowing the borders instead of extending them. Thanks to this realist policy, Atatürk could achieve to revive his country and to lead the process of forming new and modern Turkish Republic out of ruined Ottoman Empire [13,19].

There are also some characteristics of Atatürk which distinguishes him from his contemporaries. The foremost among these is sustaining an action until the end and thriving to get the best results. In this context, Turkish National Struggle movement initiated for recovering from the enemy invasion, victory in the War of Independence, removing the enemy from Anatolia and laying the foundations of a new state are all not adequate for him. He initiates the revolutions as he finds mass changes necessary in order to eliminate the problems of the nation and to reach the level of contemporary civilizations [3].

\subsection{Atatürk as a Leader}

Atatürk's founding a new state by recovering the country from the enemy invasion and initiating various revolutions to equip the country with the necessities of the time prove him as a true founding and transformational leader [8]. Atatürk expressed these utterances on August 30, 1925 on this issue: "Turkish nation with the great issues has proven that they are innovative and revolutionary. Our nation has already walked on the reform paths and attempted social revolution in previous years. However, true benefits could not be reached. Have you investigated the reason of this? It is because they have not started from the scratch. The aim of the ongoing revolutions and those we have completed is transforming the people of the Turkish Republic into a thoroughly modern and civilized society in all terms. This is the real target of our revolutions [9]." In this context, it can be emphasized that permanent and effective solutions come to the forefront in Atatürk's leadership.

Atatürk can be studied in many aspects and study findings can be presented. There exist previous studies on this issue in the literature $[2,14]$. As a result of an effective and detailed review on the field, Atatürk's leadership can be evaluated under twelve different headings [15]:

1. To be hard-working, rationalistic and brave 
2. To dedicate oneself to the country and nation (to be idealist)

3. To draw the strength from the nation and its representatives

4. To make the right decisions at the right time and implement them

5. To plan war and peace and to manage them (crisis management)

6. To share his ideas with the nation, to pay attention to the nation and to refrain from populism

7. To be ahead of time with a deep history knowledge (national vision)

8. Leadership at economics

9. To include the army in the education process of the citizens

10. To go for secular, republican and participatory governance

11. Realist nationalism based on knowledge (national policy)

12. To compete with the civilized nation in all the fields (national ideal)

According to the framework, under which Atatürk's leadership characteristics are evaluated with twelve different headings, it can be stated that Atatürk's founding and transformational leadership characteristics are represented in it. In this regard, leadership qualities come to the forefront in order to establish a new state and ensure the transformation that the state requires.

\subsection{Founding and Transformational Leadership}

The notion of founding leadership stands out most in the opinions of Machiavelli. The best resolution within the poor conditions of the society is a charismatic and powerful leader's establishing the republic by taking all the necessary actions and unifying the society under common targets. Foresight is the most crucial trait of a founding leader. The best conditions for the emergence of foresight in a leader are revealed in hard times. Moreover, a foresighted leader should communicate well with his/her society and express his/her ideas well when necessary. The second one of the prominent traits of a founding leader is realism and effective forecasting ability [16]. Constituent power trend of modern governments is establishing the sovereignty rationally, transforming the sovereignty into the general will and the general will into national integrity, and degrading national integrity to a single person's representation. This single person is the founding leader [7]. Atatürk could achieve establishing a new republic by using his founding leadership traits with the Turkish society living under poor conditions.

The notion of transformational leadership is related to creating a new vision at times changes are required, making contact with the leaders' followers by sharing this vision, being reliable and the ability of being well-respected. Some of the characteristics of transformational leadership are as follows; creating a common vision and sharing it, mental stimulation and being creative, having charismatic effect, abilities of effective communication and high motivation, being the agents of change, emotional stability, being brave, taking risks, Empowerment (Delegation), Flexible management approach, reliability and having confidence, giving importance to teamwork and lifelong learning $[10,6,12]$. Atatürk has all the characteristics of transformational leadership. He could achieve a radical transformation process in administrative, social, economic and cultural life by establishing a wholly new government out of a ruined empire.

\subsection{Purpose of the Study}

The aim of this study is to find out the opinions of pre-service teachers about Atatürk as a founding and transformational leader. Based on this basic aim, following three questions seek for answers:

- What are the opinions of pre-service teachers about Atatürk as a state founder?

- What are the opinions of pre-service teachers about the most important characteristic that distinguishes Atatürk from other Turkish state founders?

- What are the opinions of pre-service teachers about Atatürk as a transformational leader?

\section{Method}

Content analysis was used for the current study in order to identify pre-service teachers' opinions about Atatürk as a Founding and Transformational Leader. The data gathered were analyzed through frequency analysis, which is one of the content analysis techniques. Content analysis requires conceptualizing the data firstly, then organizing rationally according to the concepts that emerge, and determining the themes which describing the data. The fundamental purpose in content analysis is to reach notions and connections that can define the data gathered. The data in the content analysis are assessed thoroughly, and notions and themes, which cannot be distinguished via descriptive analysis, are revealed thanks to this analysis. As a result, the researcher tries to describe the data and uncover the truth implicated in the data through content analysis. The basic procedure in the content analysis is to gather the similar data within the framework of specific notions and themes and interpreting these by organizing in a way that readers can understand easily [20].

\subsection{Study Group}

Typical case sampling out of purposive sampling methods and convenience sampling method of qualitative research were used to choose the samples of the present study. Purposive sampling allows gathering rich and detailed data on the study topic(s) [20]. In this regard, the sampling of the study consisted of 180 pre-service teachers in the social studies teaching department of the education faculty in a 
state university. Implementation and data collection of the study took place in the 2013-2014 academic year.

\subsection{Data Collection}

An open-ended questionnaire form which was prepared by the researchers was used for the data collection in this study. For the appropriateness of the open-ended questions, four field experts and two language experts were consulted. The questions in the open-ended questionnaire form are as follows: 1- What are your opinions about Atatürk as a state founder? 2- According to you, what is the most important characteristic that distinguishes Atatürk from other Turkish state founders? 3- What are your opinions about Atatürk as a transformational leader?

\subsection{Data Analysis}

Content analysis is used for the data gathered through the data collection tool and the findings are presented in tables via frequency technique used for quantifying qualitative data and percentage distributions are reported. Furthermore, direct quotations from the opinions of participants take place in order to interpret the calculations in a more meaningful way.

\section{Findings}

In this part, the answers yielded to the questions in the open-ended questionnaire form are presented in tables by examining separately. Also, there are quotations from the replies of the pre-service teachers.

Table 1. The Opinions of Pre-service Teachers about the Question "What Are Your Opinions about Atatürk as a State Founder"

\begin{tabular}{|c|c|c|}
\hline Codes & f & \% \\
\hline $\begin{array}{c}\text { He is the leader founding the state of the Republic } \\
\text { of Turkey. }\end{array}$ & 55 & 30.56 \\
\hline He is a foresighted administrator. & 37 & 20.56 \\
\hline He is a leader with a genius personality. & 21 & 11.67 \\
\hline $\begin{array}{c}\text { He is a leader aiming to achieve national } \\
\text { independence and national sovereignty. }\end{array}$ & 20 & 11.11 \\
\hline He is a reformist leader. & 13 & 7.22 \\
\hline He is a leader taken as a role model worldwide. & 9 & 5.00 \\
\hline $\begin{array}{c}\text { He is the best administrator ever and forever in } \\
\text { Turkey. }\end{array}$ & 9 & 5.00 \\
\hline He is a fair, secular and democratic leader. & 5 & 2.77 \\
\hline He is an idealist leader. & 4 & 2.22 \\
\hline He is a republican leader. & 3 & 1.67 \\
\hline He is a perfect and unique leader. & 2 & 1.11 \\
\hline He is a leader following pacifism. & 2 & 1.11 \\
\hline Total Answers & $\mathbf{1 8 0}$ & $\mathbf{1 0 0}$ \\
\hline
\end{tabular}

As seen in Table 1, the opinions of pre-service teachers were gathered around thirteen different codes. Pre-service teachers shared their opinions about Atatürk as a state founder in the following percentages: $55 \%$ "He is the leader founding the state of the Republic of Turkey.", $37 \%$ "He is a foresighted leader.", $21 \%$ "He is a leader with a genius personality.", $20 \%$ "He is a leader aiming to achieve national independence and national sovereignty.", $13 \%$ "He is a reformist leader.", $9 \%$ for each "He is a leader taken as a role model worldwide." and "He is the best administrator ever and forever in Turkey.", $5 \%$ "He is a fair, secular and democratic leader.", $4 \%$ "He is an idealist leader.", $3 \%$ "He is a republican leader.", $2 \%$ for each "He is a perfect and unique leader." and "He is a leader following pacifism."

According to the Table 1, it is clear that the code "He is the leader founding the state of the Republic of Turkey." is the most given answer for the question "What are the opinions of pre-service teachers about Atatürk as a state founder?". The viewpoints of some of these pre-service teachers are as follows: "Atatürk saved Anatolia and the country reached prosperity with the foundation of new Turkish government thanks to him..." (ÖA51), "Atatürk established this country out of its ashes, founded Grand National Assembly of Turkey, worked for the welfare, prosperity and freedom of this nation." (ÖA96), "M. Kemal founded Turkish Republic with the national sovereignty after invasion." (ÖA49), "Atatürk established a state on sure grounds. He could withstand the threats both from the country and abroad." (ÖA91), "He is a leader transforming a ruined nation into a state again as a role model for the whole world, he is the founder of Republic." (ÖA25), "He is the leader of Turkish national resistance, re-existence of a ruined nation and the struggle for independence." (ÖA42), "Atatürk is the founder of the state of the Republic of Turkey." (ÖA6), "He is the great leader who achieved to establish a more powerful state by regenerating a wrecked nation." (ÖA18), "Atatürk established a state according to the necessities of the time, which will last for centuries-long." (ÖA71), "He is the leader founding Turkey with these words: Our humble bodies will eventually depart from life, yet Turkish Republic will maintain its existence forever." (ÖA90), "Atatürk could accomplish to found a government despite all the big nations and his enemies, he is an unforgettable leader valuing Turkish nation very much." (ÖA172), "Atatürk established Turkish Republic with his ambition, persistence and by trusting his people and brought us the sovereignty and freedom." (ÖA157). 
Table 2. The Opinions of Pre-service Teachers about the Question "According to You, What is the Most Important Characteristic that Distinguishes Atatürk from other Turkish State Founders?"

\begin{tabular}{|c|c|c|}
\hline Codes & $\mathbf{f}$ & $\mathbf{\%}$ \\
\hline He is a foresighted leader. & 45 & 25.00 \\
\hline $\begin{array}{c}\text { He is a leader who is fond of people, country and } \\
\text { nation. }\end{array}$ & 40 & 22.22 \\
\hline $\begin{array}{c}\text { He is a leader supporting the republican } \\
\text { administration. }\end{array}$ & 35 & 19.44 \\
\hline He is a reformist leader. & 13 & 7.22 \\
\hline He is an idealist leader. & 12 & 6.67 \\
\hline He is a gifted leader. & 10 & 5.56 \\
\hline He is a modern leader valuing science and arts. & 9 & 5.00 \\
\hline He is a pacifist leader. & 5 & 2.78 \\
\hline He is a leader guiding people. & 4 & 2.22 \\
\hline He is a leader valuing national unification. & 4 & 2.22 \\
\hline He is a revolutionary leader. & 3 & 1.67 \\
\hline Total Answers & $\mathbf{1 8 0}$ & $\mathbf{1 0 0}$ \\
\hline
\end{tabular}

As is seen in Table 2, the opinions of pre-service teachers can be presented below eleven different codes. Pre-service teachers shared their viewpoints about the most important feature that distinguishes Atatürk from other Turkish founders in these percentages: $45 \%$ "He is a foresighted leader.", $40 \%$ "He is a leader who is fond of people, country and nation.", 35\% "He is a leader supporting the republican administration.", $13 \%$ "He is a reformist leader.", $12 \%$ "He is an idealist leader.", $10 \%$ "He is a gifted leader.", $9 \%$ "He is a modern leader valuing science and arts.", 5\% "He is a pacifist leader.", 4\% each "He is a leader guiding people." and "He is a leader valuing national unification.", and $3 \%$ "He is a revolutionary leader."

According to the Table 2, the opinions of pre-service teachers for the question "According to You, What is the Most Important Characteristic that Distinguishes Atatürk from other Turkish State Founders?" were mostly gathered around the first coding "He is a foresighted leader." The followings are the quotations from some of these pre-service teachers: "Atatürk is a foresighted leader who sacrificed himself for his country." (ÖA70), "He is a foresighted and versatile leader who tries to glorify his nation and values the benefits of his people and the country." (ÖA23), "He is a foresighted person who can think analytically, he struggled with both the enemies and the defiance in the country, he is an honorable and victorious commander rarely seen in the World history and an administrator valuing his people." (ÖA16), "Atatürk is a person valuing his country and nation. There are many characteristics of him such as being foresighted, clever, self-sacrificing for his country, which cannot be compared to those of other administrators." (ÖA49), "His being farsighted. He always aims at doing the best thing for his country in spite of all the obstacles." (ÖA35), "His greatest trait is his farsightedness. He firstly examined all the reasons, results and process of all the actions he did." (ÖA76), "The most important characteristic of Atatürk that distinguished him from other administrators is that he could analyze well and founded a modern country with his farsightedness." (ÖA1), "His most outstanding characteristic is his being farsightedness as he did not just follow the policy of his age, but rather followed the policy of the future." (ÖA42), "The most important trait of Atatürk is his being farsightedness." (ÖA61), "The characteristic of Atatürk that separates him from the others is that he did just not found a state and turned adrift, rather, thanks to his farsightedness, he equipped this state with the features that will forever sustain the existence of it and he never appeased." (ÖA86), "His intelligence and farsightedness are the most crucial characteristics that distinguish him from the others." (ÖA62).

Table 3. The Opinions of Pre-service Teachers about the Question "What are your opinions about Atatürk as a transformational leader?"

\begin{tabular}{|c|c|c|}
\hline Codes & f & $\mathbf{\%}$ \\
\hline He is a transformational leader. & 60 & 33.33 \\
\hline He is a reformist leader. & 40 & 22.22 \\
\hline He is a leader synthetizing the East and the & 17 & 9.44 \\
\hline West. & 12 & 6.67 \\
\hline He is a role model for leaders. & 8 & 4.45 \\
\hline He is a modern leader. & 8 & 4.45 \\
\hline He is a socialist leader. & 8 & 4.45 \\
\hline He is a secular leader. & 7 & 3.89 \\
\hline He is a foresighted leader. & 6 & 3.33 \\
\hline He is a revolutionary leader. & 4 & 2.22 \\
\hline He is a conscious leader. & 3 & 1.67 \\
\hline He is a genius leader. & 2 & 1.11 \\
\hline He is a fair leader. & 2 & 1.11 \\
\hline He is an idealist leader. & 2 & 1.11 \\
\hline He is a hero leader. & 1 & 0.55 \\
\hline He is the headmaster. & $\mathbf{1 8 0}$ & $\mathbf{1 0 0}$ \\
\hline Total Answers & & \\
\hline
\end{tabular}

As it is shown in Table 3, the opinions of pre-service teachers are grouped under fifteen different codes. The pre-service teachers expressed their opinions about the characteristic that distinguishes Atatürk from other Turkish state founders with the following percentage distributions: $60 \%$ "He is a transformational leader.", $40 \%$ "He is a reformist leader.", $17 \%$ "He is a leader synthetizing the East and the West.", $12 \%$ "He is a role model for leaders.", $8 \%$ for each code "He is a modern leader.", "He is a socialist leader." and "He is a secular leader.", 7\% "He is a foresighted leader.", 6\% "He is a revolutionary leader.", 4\% "He is a conscious leader.", $3 \%$ "He is a genius leader.", $2 \%$ for each code "He is a fair leader.", "He is an idealist leader." and "He is a hero leader.", $1 \%$ "He is the headmaster."

According to the Table 3, "He is a transformational leader" is the most popular answer of the pre-service teachers for the question "What are your opinions about Atatürk as a transformational leader?" The followings are the quotations from some of the pre-service teachers: "He is a 
transformational leader taking our country and nation one step further." (ÖA68), "He performed reforms beyond his time." (ÖA13), "He is a transformist bringing the reforms in the world to our country." (ÖA91), "He is a leader trying to reform the state of the country in the best way." (ÖA55), "He is a transformational leader making multiple reforms to improve the society and reach the level of contemporary civilizations." (ÖA77), "If we have freedom and these conditions today, this is thanks to the transformational spirit of Atatürk." (ÖA46), "He is a person making the appropriate reforms at the right time." (ÖA5), "We can understand Atatürk's transformational personality in his reforms and revolutions." (ÖA21), "He is a transformist working for the development of a backward country." (ÖA15), "His reforms are based on a sound basis, not visionary ideas. Military victories are not enough for him; he dedicated himself to the nation." (ÖA23), "Republican administration was adopted and the nation got modernized by making reforms thanks to his transformational personality." (ÖA96), "He made the revolutions in order to bring Turkish nation to the level of modern civilizations and to establish a modern state. He is leader fighting with his brain; he made the actual revolution in the minds. He has given the idea of independence." (ÖA168), "Turkish nation reached the level of a modern civilization thanks to his reforms." (ÖA2), "He is a transformist valuing science and working for the modernization of his country." (ÖA17).

\section{Discussion}

Specific findings have been obtained about Atatürk's transformational and founding leadership in this study investigating the opinions of social studies pre-service teachers. The first issue to be discussed here is that this study is a pioneering research on the field. As the related literature does not include similar studies directly relevant with this topic, it is a limitation for the researchers to discuss by comparing the findings of this study to those of other relevant studies. In order to overcome this limitation, the discussion has been performed quintessentially and references have been made to certain secondary sources.

For the first question addressed to the pre-service teachers, the most salient opinions about Atatürk as a state founder can be categorized as follows: $\mathrm{He}$ is the leader founding the state of the Republic of Turkey he is a foresighted leader: he is a genius leader: he is a leader aiming to achieve national independence and national sovereignty: he is a reformist leader. As a result of this categorization, the emphasis on being a founder is an expected result. Farsightedness, national independence-sovereignty target and innovativeness are the characteristics that are expected to emerge in the circumstances of Atatürk. However, having a genius personality is an outstanding characteristic. In the studies on the leadership of Atatürk, it is stated that leadership notion has to be examined in terms of genius. This is because, in order to be a founding and transformational leader, it is essential to have the innate ability of achieving extraordinary things, an excellent creativity, a deep understanding ability, to show his/her people what he/she sees / to walk together on the way guided by him/her and a great patience [15]. Moreover, the most prominent trait of a founding leader is farsightedness [10]. National independence-sovereignty targets are two essential concepts in the process of Atatürk's founding a state and transformation [4]. It can be asserted that such opinions of pre-service teachers about Atatürk's leadership are correlated with this issue.

The most popular viewpoints of pre-service teachers for the second question about the most important characteristic that distinguishes Atatürk from other Turkish state founders are categorized in this way: he is a foresighted leader; he is a leader who is fond of people, nation and country; he is a leader supporting the republican administration; he is a reformist leader; he is an idealist leader and he is a gifted leader. The characteristic of being foresightedness is similar to the categories in the first question. The most crucial finding here is the category of being a leader who is fond of people, country and nation. Likewise, it can be asserted that one of the most important characteristics of a founding and a transformational leader is internalizing humanity and pacifism (peace at home, peace in the world) so as to create big changes [17]. Moreover, the following utterance of him can be given as an example for Atatürk's being an idealist leader: "The point is not death, rather, realizing our ideals before death" [1].

The followings are the most outstanding categories of the viewpoints of pre-service teachers for the third question about Atatürk as a transformational leader: he is a transformational leader; he is a reformist leader; he is a leader synthetizing the East and the West, and he is a role model for leaders. It is not unexpected that transformation characteristic stands out in the answers of the pre-service teachers. Atatürk is supposed to open to new ideas in order to reflect his transformational ability. Also, he has been a role model by firstly trying on himself all the new innovations that he proposed for his society. From this point of view, it can be argued that the answers of pre-service teachers have internal consistency. Thus, it can be said that Atatürk is a great transformational leader having all these features [5]. The stunning finding for this question is that he is a leader synthetizing the East and the West. Pre-service teachers recognize that Atatürk took the most modern civilization of that time as an example for a real transformation. This is because Atatürk performed synthesis movements for his reforms by taking mostly Western civilization as an example [18].

The framework resulting from the investigation of pre-service teachers' opinions can be integrally associated with the leadership notion of Max Weber. Weber relates charismatic leadership to hard times. A charismatic leader has great feats of strength and outstanding features taken as an example and his/her people are in full devotion to him 
[11]. From this angle, Atatürk, who is a founding and transformational leader according to the opinions of pre-service teachers, can also be characterized as a charismatic leader.

\section{Conclusions}

The aim of this study is to identify the opinions of pre-service teachers about Atatürk as a founding and transformational leader. The findings of the study illustrate that the opinions of pre-service teachers about Atatürk as a founding and transformational leader mostly gather around the points "He is a leader founding the state of the Republic of Turkey", "He is a foresighted leader." and "He is a transformational leader." As a result, the emergent qualitative pattern proves that the opinions of pre-service teachers about Atatürk as a founding and transformational leader show consistency. Pre-service teachers, who will teach Atatürk's leadership to their students within the context of social studies, are aware of his leadership features. This was favorable for the researchers as each pre-service teacher is the leader of his/her students about education.

\section{Recommendations}

As there exists no research in the related literature about the opinions of pre-service teachers on Atatürk as a founding and transformational leader, it is essential to conduct studies with different samples and methods. It is supposed that more comprehensive studies on this issue will be useful for the relevant literature.

\section{REFERENCES}

[1] Aksan, A. (1986). Atatürk der ki. Ankara: Kültür ve Turizm Bakanlığı Yayınları.

[2] Altıntop, Ö., Reca, Ö. F. (2011). Atatürk'ün liderlik sırlart. İstanbul: MY Kitap.

[3] Atatürk, K. (2007). Nutuk 1919 - 1927. Ankara: Atatürk Araştırma Merkezi Yayınları.
[4] Aydınel, S. (2008). Atatürkçülükte ulusal hedef ulusal politika ulusal strateji. Ankara: Siyasal Kitabevi.

[5] Bozdağ, İ. (1988). Atatürk'ün evrensel boyutlart. Ankara: Kültür ve Turizm Bakanlığı Yayınları.

[6] Çelik, V. (1998). Eğitimde dönüşümcü liderlik. Kuram ve Uygulamada Eğitim Yönetimi Dergisi, 4(4), 423-442.

[7] Çetin, H. (2002). Modern devletin egemenlik (kurucu iktidar) döngüsü. Abant İzzet Baysal Üniversitesi Sosyal Bilimler Enstitüsü Dergisi, 3(2): 56-75.

[8] Dönmez, C. (2006). Atatürk'ün devlet adamlığı vasfi ve bunun saltanattan cumhuriyete geçişteki rolü. Abant İzet Baysal Üniversitesi Sosyal Bilimler Enstitüsü Dergisi, 2(13): 11-23.

[9] Dumoulin, D. (2000). Atatürk'ten Düşünceler. Ankara: Atatürk Araştırma Merkezi Yayınları.

[10] Eraslan, L. (2004). Liderlikte post-modern bir paradigma: dönüşümcü liderlik. Uluslararası Ínsan Bilimleri Dergisi, 1(1): $1-32$.

[11] Eroğlu, H. (1988). Atatürk'ün üstün kişiliği. In Atatürkçülük, Atatürk ve Atatürkçülüğe ilişkin makaleler (p. 39-57). İstanbul: Milli Eğitim Basımevi.

[12] Karip, E. (1998). Dönüşümcü liderlik. Kuram ve Uygulamada Eğitim Yönetimi Dergisi, 4(4), 443-465.

[13] Kinross, L. (1999). Atatürk, bir milletin yeniden doğuşu. Çev. N. Sander, İstanbul: Altın Kitaplar.

[14] Mert, Y., Açıkgöz, C. (2010). Atatürk'ün liderlik sırları. Ankara: Tutku Yayınevi.

[15] Özdemir, H. (2006). Atatürk'in liderlik sirlart. İstanbul: Remzi Kitabevi.

[16] Öztürk, A. (2013). Machiavelli düşüncesinde cumhuriyetçi özgürlük ve kurucu lider imgesi. Ankara Üniversitesi $S B F$ Dergisi, 68(2): 181-204.

[17] Palazoğlu, A. B. (2007). Atatürk kimdir Atatürk'ün devlet adamlığı dünyada barış. Ankara: Ebabil Yayıncılık.

[18] Safa, P. (1988). Türk inkllabına bakışlar. Ankara: Atatürk Araștırma Merkezi Yayınları.

[19] Yavuz, Ü. (1990). Atatürk imparatorluktan milli devlete. Ankara: Türk Tarih Kurumu Basımevi.

[20] Yıldırım, A. ve Şimşek, H. (2008). Nitel araştırma yöntemleri. Ankara: Seçkin Yayıncılık. 